\title{
Optimal management of patients with non-small cell lung cancer with ipsilateral mediastinal lymph node metastases
}

Richard J. Battafarano, MD, PhD

See related article on page 1229.
From Barnes-Jewish Hospital, St Louis, Mo. Received for publication Oct 25, 2005; accepted for publication Nov 2, 2005.

Address for reprints: Richard J. Battafarano, MD, One Barnes-Jewish Plaza, 33107 Queeny Tower, St Louis, MO 63110-1013 (E-mail: battafarano@msnotes.wustl.edu).

J Thorac Cardiovasc Surg 2006;131:1227-8 $0022-5223 / \$ 32.00$

Copyright (C) 2006 by The American Association for Thoracic Surgery

doi:10.1016/j.jtcvs.2005.11.011
7 he optimal management of patients with non-small cell lung cancer with ipsilateral mediastinal lymph node metastases (N2) remains controversial. Patients with N2 disease represent a heterogeneous group that includes patients with microscopic disease in a single lymph node and patients with bulky metastatic adenopathy at multiple ipsilateral lymph node stations. Although many reports have described the feasibility of neoadjuvant therapy followed by resection in these patients, residual N2 disease at the time of resection is associated with limited survival. ${ }^{1,2}$ In addition, pneumonectomy performed after neoadjuvant therapy has been associated with significant perioperative morbidity and mortality. 3,4

In this issue of the Journal, Dr Cerfolio and his colleagues ${ }^{5}$ describe their experience with restaging the mediastinum after induction chemoradiation therapy using integrated positron emission tomography/computed tomography (PET/CT) imaging in 93 patients with pathologically proven N2 disease. Restaging with this imaging modality missed residual N2 disease in 13 of $65(20 \%)$ patients with "negative" restaging evaluations and falsely suggested N2 disease in 7 of $28(25 \%)$ patients with "positive" restaging evaluations. Further analysis demonstrated that a decrease in the standardized uptake value (SUV) of the primary tumor of more than $75 \%$ or a decrease in the SUV of the N2 node initially involved with metastatic disease of more than $50 \%$ was predictive of a significant response to the induction therapy.

Although this study highlights some of the limitations of integrated PET/CT restaging of the mediastinum after induction chemoradiation therapy, these results do not suggest that it is not a useful restaging modality. First of all, integrated PET/CT is significantly better than CT imaging alone for identifying patients who are complete pathologic responders and those who had no evidence of residual disease in their hilar or mediastinal lymph nodes. In an effort to limit the number of unnecessary thoracotomies in patients with persistent N2 disease (false-negative studies), the authors suggest that rebiopsy of all nodal stations that originally demonstrated metastatic disease before induction therapy could be performed by using minimally invasive techniques such as endoscopic ultrasonography with fine-needle aspirate or video-assisted thoracic surgery. Similarly, biopsy of positive nodes on repeat PET/CT staging should help to identify those patients with persistent metastatic disease and those with postinduction therapy inflammation.

The ultimate goal in the management of patients with non-small cell lung cancer who have N2 disease is to differentiate those patients who most likely will benefit from resection after induction therapy from those who are better served with definitive chemoradiation therapy. Favorable prognostic variables include radiographically occult disease, metastases to a single nodal station (especially station $\mathrm{V}$ nodes in patients with left upper lobe tumors), and downstaging from N2 to N0-N1 disease. $^{6-9}$ In these cases, it is reasonable to recommend aggressive trimodality therapy in otherwise healthy patients. For patients with multistation nodal disease, surgical resection after induction therapy should be reserved for those patients whose primary tumor and residual nodal metastases can be resected completely without pneumonectomy. Final results from the prospective randomized trial comparing definitive chemoradiation therapy to induction chemoradiation followed by surgery in patients with N2 disease (Intergroup Trial 0139) should help to answer important questions associated with this challenging clinical problem. 


\section{References}

1. Lorent N, De Leyn P, Lievens Y, Verbeken E, Nackaerts K, Dooms C, et al. Long-term survival of surgically staged IIIA-N2 non-smallcell lung cancer treated with surgical combined modality approach: analysis of a 7-year prospective experience. Ann Oncol. 2004;15: 1645-53.

2. Port JL, Korst RJ, Lee PC, Levin M A, Becker DE, Keresztes R, et al. Surgical resection for residual N2 disease after induction chemotherapy. Ann Thorac Surg. 2005;79:1686-90.

3. Martin J, Ginsberg RJ, Abolhoda A, Bains MS, Downey RJ, Korst RJ, et al. Morbidity and mortality after neoadjuvant therapy for lung cancer: the risks of right pneumonectomy. Ann Thorac Surg. 2001; 72:1149-54.

4. Doddoli C, Barlesi F, Trousse D, Robitail S, Yena S, Astoul P, et al. One hundred consecutive pneumonectomies after induction therapy for non-small cell lung cancer: an uncertain balance between risks and benefits. J Thorac Cardiovasc Surg. 2005;130:416-25.

5. Cerfolio RJ, Bryant AS, Ojha B. Restaging patients with N2 (stage IIIa) non-small cell lung cancer after neoadjuvant chemoradiother- apy: a prospective study. J Thorac Cardiovasc Surg. 2006;131: 1229-35.

6. Inoue M, Sawabata N, Takeda S, Ohta M, Ohno Y, Maeda H. Results of surgical intervention for p-stage IIIA (N2) non-small cell lung cancer: acceptable prognosis predicted by complete resection in patients with single N2 disease with primary tumor in the upper lobe. J Thorac Cardiovasc Surg. 2004;127:1100-6.

7. Tanaka F, Yanagihara K, Otake Y, Kawano Y, Miyahara R, Takenaka K, et al. Prognostic factors in resected pathologic (p-) stage IIIA-N2, non-small-cell lung cancer. Ann Surg Oncol. 2004;11: 612-8.

8. Keller SM, Vangel MG, Wagner H, Schiller JH, Herskovic A, Komaki $\mathrm{R}$, et al. Prolonged survival in patients with resected non-small cell lung cancer and single-level N2 disease. J Thorac Cardiovasc Surg. 2004; 128:130-7.

9. Casali C, Stefani A, Natali P, Rossi G, Morandi U. Prognostic factors in surgically resected N2 non-small cell lung cancer: the importance of patterns of mediastinal lymph nodes metastases. Eur J Cardiothorac Surg. 2005;28:33-8

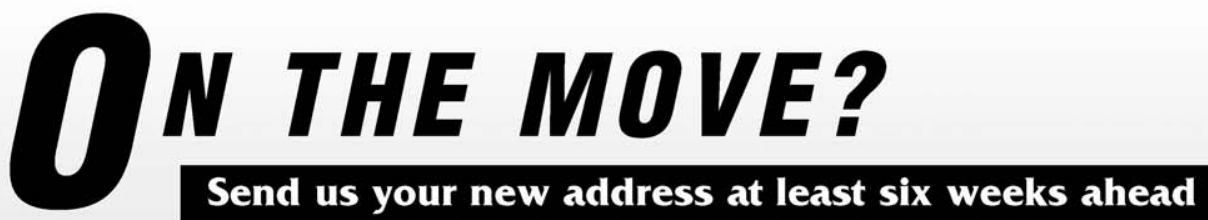

Don't miss a single issue of the journal! To ensure prompt service when you change your address, please photocopy and complete the form below.

Please send your change of address notification at least six weeks before your move to ensure continued service. We regret we cannot guarantee replacement of issues missed due to late notification.

\section{JOURNAL TITLE:}

Fill in the title of the journal here.

OLD ADDRESS:

Affix the address label from a recent issue of the journal here.

\section{NEW ADDRESS:}

Clearly print your new address here.

Name

Address

City/State/ZIP

\section{COPY AND MAIL THIS FORM TO:}

Elsevier Inc.

Subscription Customer Service

6277 Sea Harbor Dr

Orlando, FL 32887
OR FAX TO:

407-363-9661

OR E-mail:

elspcs@elsevier.com
OR PHONE:

800-654-2452

Outside the U.S., call

407-345-4000 